\title{
Effect of pH on Inhibition of Plasmid-carrying Cultures of Staphylococcus aureus by Lipids
}

\author{
By JAY NAIDOO \\ Department of Bacteriology, Institute of Dermatology, Homerton Grove, London E9 6BX
}

(Received 12 August 1980; revised 4 November 1980)

The inhibition of Staphylococcus aureus by fatty acids was $\mathrm{pH}$ dependent. The inhibitory properties of myristic acid were greater at $\mathrm{pH} 5.5$ than at $\mathrm{pH} 7$, whereas those of linoleic acid were less at $\mathrm{pH} 5.5$ than at $\mathrm{pH}$ 7. Seven clinical penicillin-resistant cultures survived better in the presence of linoleic acid at $\mathrm{pH} 5.5$ than did their sensitive counterparts. The resistance to linoleic acid in most plasmid-carrying cultures at $\mathrm{pH} 5.5$ was probably not due to the production of penicillinase, but to some other determinants carried by the plasmid.

\section{INTRODUCTION}

Noble (1977) described variation in the distribution of antibiotic resistance in Staphylococcus aureus strains isolated from the skin and nose of patients in a skin hospital. He found that, in several patients, isolates from the skin were more often resistant to penicillin or to tetracycline than were isolates of the same phage type from the same patient's anterior nares. The reverse distribution rarely occurred. This implies selection of antibiotic-resistant variants by factors on the skin, or of sensitive variants in the nose.

Butcher et al. (1976) reported that a strain of $S$. aureus (NCTC 8325) became more susceptible to the inhibitory effect of linoleic acid when the 'penicillinase plasmid' PI258 was introduced. Carriage of a plasmid mediating resistance to tetracycline had no effect on sensitivity to linoleic acid. These findings are apparently in conflict with natural events, since linoleic acid, a constituent of skin lipid, should select sensitive variants on the skin (Noble, 1977). However, the experiments of Butcher et al. (1976) were most probably made at neutral $\mathrm{pH}$, and although the $\mathrm{pH}$ of nasal secretions is about 7, that of the skin is about 5.5 (Noble, 1981). Greenway \& Dyke (1979) reported that an acid pH could modify the response of $S$. aureus 8325 to fatty acids, confirming the general observations of Altenbern (1977); however, the combined effect of $\mathrm{pH}$ and plasmid carriage was not studied. This paper reports studies on the inhibition of $S$. aureus by some components of skin lipid and attempts to give a plausible explanation for the distribution of resistant and sensitive variants.

\section{METHODS}

Strains. Staphylococcus aureus strains CL2 (non-typable), HO4 (phage type 94/96), J44 (phage type I, III, IV), J66 (phage type 3A/3C), PI (phage type I, IV), HA4 (phage type 96), BU2 (phage type 79/95), Git (phage type 29/79/80/42E/54/85) and AA3 (phage type 75) were isolated from the nose and skin of patients. In addition, strain NCTC 8325 designated $8325 \mathrm{~N}$ to indicate that it contains no plasmid, 8325 pen which contains the penicillinase plasmid PI258, and 8325tet which contains the tetracycline resistance plasmid T1044 were kindly supplied by D. L. A. Greenway. The cadmium-sensitive variant of strain NCTC 9789 (PS80) was obtained after exposure of the strain to sodium dodecyl sulphate (SDS).

Characterization of strains. Antibiotic sensitivity testing was carried out by a modified Kirby-Bauer technique on Oxoid Mueller Hinton agar (CM337) at $37^{\circ} \mathrm{C}\left(30^{\circ} \mathrm{C}\right.$ for methicillin). Oxoid sensitivity discs contained the 
following antibiotics: penicillin, 10 units; tetracycline, $30 \mu \mathrm{g}$; neomycin, $30 \mu \mathrm{g}$; erythromycin, $15 \mu \mathrm{g}$; gentamicin, $10 \mu \mathrm{g}$; clindamycin, $2 \mu \mathrm{g}$; methicillin, $5 \mu \mathrm{g}$.

Phage typing was carried out with the International Set of Typing Phages kindly supplied by Mrs M. de Saxe (Central Public Health Laboratories, Colindale).

Minimum inhibitory concentrations (m.i.c.) of cadmium were determined by the plate incorporation method, using cadmium acetate in Oxoid blood agar base (CM55). Cultures were incubated overnight in nutrient broth, diluted $1 / 100$ and spot inoculated on to the cadmium agar plates. The m.i.c. was taken as the lowest concentration which prevented any growth of the organism.

Loss of plasmid-coded resistances from clinical strains was detected by exposure to SDS (Sonstein \& Baldwin, 1972). Single plasmids in antibiotic-resistant strains CL2, HO4, J44, J66, PI, HA4, BU2, AA3, 8325 and 9789 were detected by the technique of Clewell \& Helinski (1969), modified for staphylococci, and agarose gel electrophoresis (Meyers et al., 1976). Strain Git contained a small cryptic plasmid in addition to a plasmid coding for antibiotic resistance. Each sensitive variant had the same bacteriophage type as that of the parent strain.

Inhibition of $S$. aureus by fatty acids. Fatty acids tested were linoleic acid (cis,cis), myristic acid, lauric acid, oleic acid (cis), palmitic acid and stearic acid. Strains were grown overnight on agar supplemented with penicillin $\left(10 \mu \mathrm{g} \mathrm{ml}^{-1}\right)$ or tetracycline $\left(10 \mu \mathrm{g} \mathrm{ml}^{-1}\right)$ or on nutrient agar. Pairs of resistant and sensitive variants of the same strain were used for each experiment. Culture pairs were each suspended in CY medium (Novick, 1963) and brought to a turbidity of about 0.4 (approx. $10^{5}$ colony-forming units $\mathrm{ml}^{-1}$ ). One $\mathrm{ml}$ of each culture was inoculated into $50 \mathrm{ml}$ prewarmed CY broth in $250 \mathrm{ml}$ Erlenmeyer flasks. After incubation with shaking at $37{ }^{\circ} \mathrm{C}$ for $1.5 \mathrm{~h}$, the temperature was reduced to $33{ }^{\circ} \mathrm{C}$ (approx. skin temperature) and the medium was brought to the required $\mathrm{pH}$ by adding $1 \mathrm{~m}-\mathrm{NaOH}$ or $2 \mathrm{M}-\mathrm{HCl}$ (the required volumes were determined by adjusting a sample using a direct reading $\mathrm{pH}$ meter). The appropriate fatty acid dissolved in alcohol $\left(5 \mathrm{mg} \mathrm{ml}^{-1}\right)$ was added to give a final concentration of 4 or $5 \mu \mathrm{g} \mathrm{ml}^{-1}$; this is approximately the maximum level found on skin $\left(\mu \mathrm{g} \mathrm{cm}^{-2}\right)$ (Noble, 1981). An equal volume of alcohol alone was added to control flasks. Growth was then followed by measuring the turbidity at hourly intervals on a SP1300 Pye Unicam photometer at $370-515 \mathrm{~nm}$.

Similarly, cholesterol, cholesterol esters (cholesterol linoleate, oleate, stearate and palmitate), squalene and skin steroids (5-dihydrotestosterone, 5-androstan-3 $\beta, 17 \beta$-diol, androsterone and dihydroepiandrosterone) were dissolved in alcohol and added to cultures to give the appropriate concentrations. Equal volumes of alcohol alone were always added to control cultures.

Fatty acids, cholesterol, cholesterol esters, squalene, steroids and SDS were from Sigma.

\section{RES ULTS}

\section{Inhibition of $S$. aureus by fatty acids}

Linoleic acid. At pH 7 the inhibitory effect of linoleic acid on strain 8325 (Fig. $1 a$ ) was as described by Butcher et al. (1976); that is, the strain bearing the penicillinase plasmid PI258 was more strongly inhibited by linoleic acid $\left(5 \mu \mathrm{g} \mathrm{ml}^{-1}\right)$ than was the antibiotic-sensitive strain. At pH 5.5, however, the inhibitory effect of the fatty acid was less and there was very little difference in growth between the strain bearing the penicillinase plasmid and the plasmid-free strain (Fig. $1 b$ ).

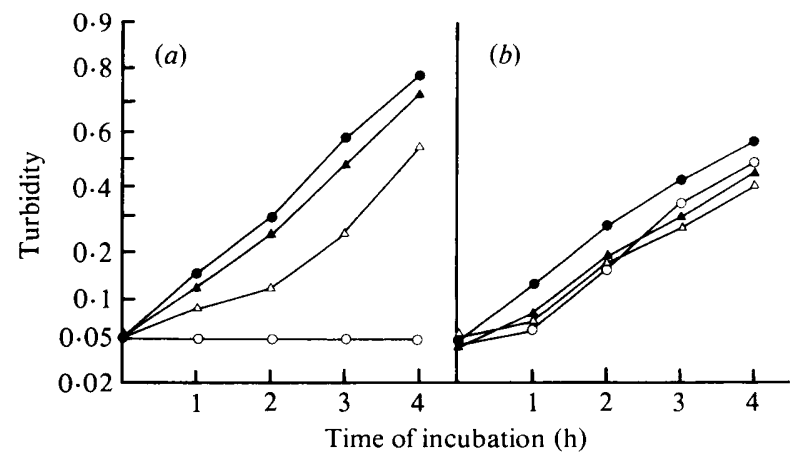

Fig. 1. Effect of linoleic acid at pH $7(a)$ and $\mathrm{pH} 5.5(b)$ on $S$. aureus strain 8325 resistant to penicillin $\left(\mathrm{O}, 0 ; \mathrm{O}, 5 \mu \mathrm{g}\right.$ linoleic acid $\left.\mathrm{ml}^{-1}\right)$ and sensitive to penicillin $\left(\Delta, 0 ; \Delta, 5 \mu \mathrm{g}\right.$ linoleic acid $\left.\mathrm{ml}^{-1}\right)$. 
Table 1. Turbidity of S. aureus cultures after 4 growth at pH 5.5 and $p H 7$ with and without linoleic acid $\left(4 \mu \mathrm{g} \mathrm{ml}^{-1}\right)$

\begin{tabular}{|c|c|c|c|c|c|c|}
\hline \multirow[b]{2}{*}{ Strain } & \multirow[b]{2}{*}{ Resistance* } & \multirow[b]{2}{*}{$\begin{array}{c}\text { Cadmium } \\
\text { m.i.c. } \\
\left(\mu \mathrm{g} \mathrm{ml}^{-1}\right)\end{array}$} & \multicolumn{2}{|c|}{ pH 5.5} & \multicolumn{2}{|c|}{$\mathrm{pH} 7$} \\
\hline & & & Control & $\begin{array}{l}+ \text { Linoleic } \\
\text { acid }\end{array}$ & Control & $+\underset{\text { acid }}{\text { Linoleic }}$ \\
\hline $8325 \mathrm{~N}$ & S/All & 16 & 0.58 & 0.51 & 0.69 & 0.61 \\
\hline 8325pen & $\mathrm{R} / \mathrm{P}, \mathrm{E}$ & 128 & 0.50 & 0.50 & 0.62 & 0.29 \\
\hline 8325 tet & $\mathrm{R} / \mathrm{T}$ & 16 & 0.51 & 0.57 & 0.65 & 0.70 \\
\hline CL2 & S/All & 16 & 0.58 & 0.04 & 0.80 & 0.01 \\
\hline CL2 & $\mathrm{R} / \mathrm{P}$ & 64 & 0.56 & 0.32 & 0.75 & 0.08 \\
\hline CL2 & S/All & 16 & 0.51 & $0 \cdot 10$ & 0.71 & 0.02 \\
\hline CL2 & $\mathrm{R} / \mathrm{P}$ & 64 & 0.45 & 0.37 & 0.80 & 0.07 \\
\hline CL2 & S/All & 16 & 0.52 & 0.13 & 0.68 & 0.02 \\
\hline CL2 & $\mathrm{R} / \mathrm{P}$ & 64 & 0.60 & 0.57 & 0.70 & 0.06 \\
\hline $\mathrm{HO} 4$ & S/All & 16 & 0.56 & $0 \cdot 15$ & 0.68 & 0.02 \\
\hline $\mathrm{HO} 4$ & $\mathrm{R} / \mathrm{P}$ & 64 & 0.47 & 0.30 & 0.75 & 0.01 \\
\hline J44 & S/All & 16 & 0.25 & 0.03 & 0.63 & 0.03 \\
\hline J44 & $\mathrm{R} / \mathrm{P}$ & 64 & 0.44 & 0.37 & 0.77 & 0.03 \\
\hline J66 & S/All & 16 & 0.45 & 0.30 & 0.69 & 0.21 \\
\hline J66 & $\mathrm{R} / \mathrm{P}$ & 128 & 0.45 & 0.40 & 0.78 & 0.20 \\
\hline PI & S/All & 16 & 0.42 & 0.22 & 0.73 & 0.20 \\
\hline PI & $\mathbf{R} / \mathbf{P}$ & 64 & 0.47 & 0.44 & 0.77 & $0 \cdot 20$ \\
\hline HA4 & S/All & 16 & 0.45 & 0.22 & 0.51 & 0.20 \\
\hline HA4 & $\mathrm{R} / \mathrm{P}$ & 64 & 0.45 & 0.43 & 0.54 & 0.20 \\
\hline BU2 & S/All & 16 & 0.40 & 0.37 & 0.80 & 0.02 \\
\hline BU2 & $\mathrm{R} / \mathrm{P}$ & 64 & 0.57 & 0.52 & 0.88 & 0.03 \\
\hline Git & S/All & 64 & 0.55 & 0.42 & 0.72 & 0.15 \\
\hline Git & $\mathrm{R} / \mathrm{P}$ & 128 & 0.58 & 0.40 & 0.80 & 0.13 \\
\hline 9789 & $\mathrm{R} / \mathrm{P}$ & 8 & 0.55 & 0.06 & 0.80 & 0.02 \\
\hline 9789 & $R / P$ & 128 & 0.72 & 0.58 & 0.80 & 0.05 \\
\hline AA3 & S/All & 16 & 0.50 & $0 \cdot 10$ & 0.78 & 0.01 \\
\hline AA3 & $\mathrm{R} / \mathrm{T}$ & 16 & 0.38 & 0.08 & 0.73 & 0.01 \\
\hline
\end{tabular}

* S/All, sensitive to all tested antibiotics (see Methods); R/P,T,E, resistant to penicillin, tetracycline and erythromycin, respectively.

With the clinical isolates slightly different results were obtained. Table 1 shows the turbidity of the cultures after $4 \mathrm{~h}$ growth with $4 \mu \mathrm{g}$ linoleic acid $\mathrm{ml}^{-1}$. All cultures except strain 8325 were inhibited more at $\mathrm{pH} 7$ than $\mathrm{pH} 5.5$ by linoleic acid. The penicillin-resistant and penicillin-sensitive isolates of each clinical strain were inhibited equally at $\mathrm{pH} 7$, but at pH 5.5 the penicillin-sensitive cultures were inhibited more than resistant cultures. This is illustrated for strain CL2 (Fig. 2). Experiments were repeated using different batches of media, different preparations of fatty acids and subcultures of strains. The results for strain CL2 studied on three separate occasions are included in Table 1. Although growth of the strain as a whole differed slightly on the different occasions, the penicillin-resistant culture consistently grew better than the sensitive culture in the presence of linoleic acid at pH 5.5 . This also occurred with the other clinical strains. No effect of plasmid carriage was seen with strains bearing the tetracycline resistance plasmid (Table 1).

Results for strain Git were different from the others in that there was very little difference in growth between the penicillin-resistant and penicillin-sensitive isolates in the presence of the fatty acid at $\mathrm{pH} 5 \cdot 5$. This apparent anomaly was studied further. Both the penicillin-resistant and penicillin-sensitive isolates of this strain were resistant to cadmium (Table 1). Loss of 


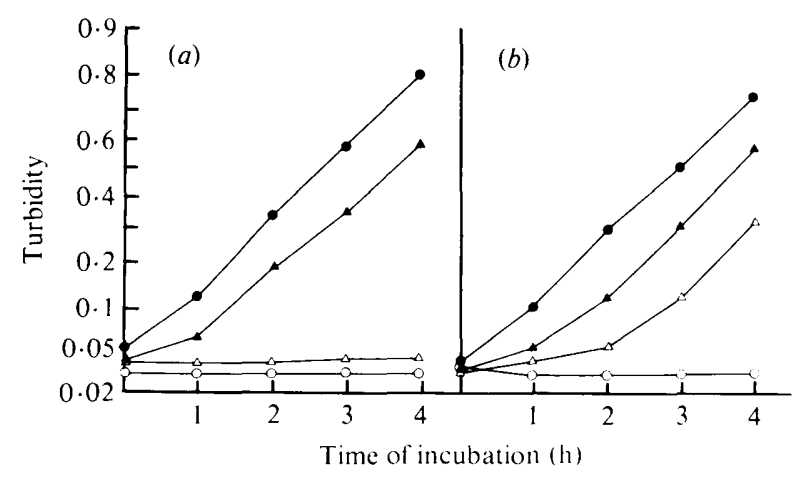

Fig. 2. Effect of linoleic acid on the growth of the penicillin-sensitive (a) and penicillin-resistant $(b)$ variants of $S$. aureus strain $\mathrm{CL} 2$ at $\mathrm{pH} 7\left(\boldsymbol{O}, 0 ; \bigcirc, 4 \mu \mathrm{g}\right.$ linoleic acid $\left.\mathrm{ml}^{-1}\right)$ and $\mathrm{pH} 5 \cdot 5(\Delta, 0 ; \Delta, 4 \mu \mathrm{g}$ linoleic acid $\mathrm{ml}^{-1}$ ).

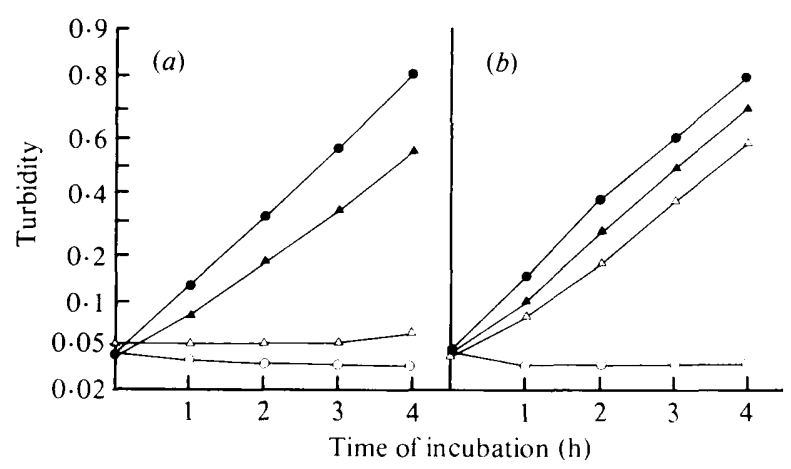

Fig. 3. Effect of linoleic acid on the growth of the cadmium-sensitive (a) and cadmium-resistant $(b)$ variants of $S$. aureus strain 9789 at $\mathrm{pH} 7\left(\boldsymbol{O}, 0 ; 0,4 \mu \mathrm{g}\right.$ linoleic acid $\left.\mathrm{ml}^{-1}\right)$ and $\mathrm{pH} 5.5(\Delta, 0 ; \triangle, 4 \mu \mathrm{g}$ linoleic acid $\mathrm{ml}^{-1}$ ).

penicillinase production from this strain was not accompanied by loss of cadmium resistance as in the other strains. This suggested that it was not the penicillinase genes that were responsible for the increased survival in linoleic acid but some other determinant on the plasmid, e.g. metal ion resistance. To study this further, strain NCTC 9789 was used which has chromosomal penicillin resistance and a separate plasmid which bears the genes for resistance to metal ions including cadmium (Asheshov, 1966, 1969). The variant of 9789 which had become sensitive to metal ions was sensitive to the inhibitory effects of linoleic acid at $\mathrm{pH} 5.5$ while the parent was not (Fig. 3), although both variants were still penicillinase producers.

Other fatty acids. Both myristic and lauric acids were more inhibitory at $\mathrm{pH} 5 \cdot 5$ than at $\mathrm{pH} 7$ (Table 2), and lauric acid was slightly more inhibitory to the penicillin-resistant than to the sensitive variant of strain CL2 at $\mathrm{pH} 5 \cdot 5$. Oleic, palmitic and stearic acids were not inhibitory at the concentration used at either $\mathrm{pH}$ to strains bearing plasmids or their sensitive counterparts. No effect of the tetracycline resistance plasmid in the clinical strain AA3 was seen with any fatty acid.

\section{Inhibition of $S$. aureus by free cholesterol and cholesterol esters}

Cholesterol alone had no significant effect on the growth of either variant of strain CL2 at either $\mathrm{pH}$. However, when $10 \mu \mathrm{g}$ cholesterol $\mathrm{ml}^{-1}$ was added to medium containing $4 \mu \mathrm{g}$ 
Table 2. Turbidity of $S$. aureus cultures after 4 hrowth at pH $5 \cdot 5$ and $\mathrm{pH} 7$ with and without different fatty acids $\left(4 \mu \mathrm{g} \mathrm{ml^{-1 }}\right)$

\begin{tabular}{|c|c|c|c|c|c|c|}
\hline \multirow{2}{*}{$\begin{array}{l}\text { Fatty } \\
\text { acid }\end{array}$} & \multirow[b]{2}{*}{ Strain } & \multirow[b]{2}{*}{ Resistance* } & \multicolumn{2}{|c|}{$\overbrace{}^{\mathrm{pH} 5.5}$} & \multicolumn{2}{|c|}{$\mathrm{pH} 7$} \\
\hline & & & Control & + Fatty acid & Control & + Fatty acid \\
\hline \multirow[t]{2}{*}{ Myristic } & $\begin{array}{l}\text { CL2 } \\
\text { CL2 }\end{array}$ & $\begin{array}{l}\text { S/All } \\
\text { R/P }\end{array}$ & $\begin{array}{l}0.59 \\
0.67\end{array}$ & $\begin{array}{l}0.08 \\
0.04\end{array}$ & $\begin{array}{l}0.85 \\
0.85\end{array}$ & $\begin{array}{l}0.77 \\
0.75\end{array}$ \\
\hline & $\begin{array}{l}\mathrm{AA} 3 \\
\mathrm{AA} 3\end{array}$ & $\begin{array}{l}\text { S/All } \\
\text { R/T }\end{array}$ & $\begin{array}{l}0.75 \\
0.71\end{array}$ & $\begin{array}{l}0.07 \\
0 \cdot 10\end{array}$ & $\begin{array}{l}0.85 \\
0.79\end{array}$ & $\begin{array}{l}0.82 \\
0.76\end{array}$ \\
\hline \multirow[t]{2}{*}{ Lauric } & $\begin{array}{l}\text { CL2 } \\
\text { CL2 }\end{array}$ & $\begin{array}{l}\text { S/All } \\
\mathrm{R} / \mathrm{P}\end{array}$ & $\begin{array}{l}0.59 \\
0.57\end{array}$ & $\begin{array}{l}0.25 \\
0.15\end{array}$ & $\begin{array}{l}0.78 \\
0.78\end{array}$ & $\begin{array}{l}0.85 \\
0.81\end{array}$ \\
\hline & $\begin{array}{l}\text { AA3 } \\
\text { AA3 }\end{array}$ & $\begin{array}{l}\text { S/All } \\
\text { R/T }\end{array}$ & $\begin{array}{l}0.56 \\
0.52\end{array}$ & $\begin{array}{l}0.34 \\
0.40\end{array}$ & $\begin{array}{l}0.65 \\
0.76\end{array}$ & $\begin{array}{l}0.72 \\
0.74\end{array}$ \\
\hline \multirow[t]{2}{*}{ Oleic } & $\begin{array}{l}\text { CL2 } \\
\text { CL2 }\end{array}$ & $\begin{array}{l}\text { S/All } \\
\text { R/P }\end{array}$ & $\begin{array}{l}0.67 \\
0.75\end{array}$ & $\begin{array}{l}0.60 \\
0.64\end{array}$ & $\begin{array}{l}0.87 \\
0.80\end{array}$ & $\begin{array}{l}0.80 \\
0.87\end{array}$ \\
\hline & $\begin{array}{l}\text { AA3 } \\
\text { AA3 }\end{array}$ & $\begin{array}{l}\text { S/All } \\
\text { R/T }\end{array}$ & $\begin{array}{l}0.54 \\
0.45\end{array}$ & $\begin{array}{l}0.51 \\
0.52\end{array}$ & $\begin{array}{l}0.70 \\
0.75\end{array}$ & $\begin{array}{l}0.77 \\
0.76\end{array}$ \\
\hline \multirow[t]{2}{*}{ Palmitic } & $\begin{array}{l}\text { CL2 } \\
\text { CL2 }\end{array}$ & $\begin{array}{l}\text { S/All } \\
\text { R/P }\end{array}$ & $\begin{array}{l}0.51 \\
0.53\end{array}$ & $\begin{array}{l}0.46 \\
0.56\end{array}$ & $\begin{array}{l}0.70 \\
0.66\end{array}$ & $\begin{array}{l}0.67 \\
0.72\end{array}$ \\
\hline & $\begin{array}{l}\mathrm{AA3} \\
\mathrm{AA3}\end{array}$ & $\begin{array}{l}\text { S/All } \\
\text { R/T }\end{array}$ & $\begin{array}{l}0.43 \\
0.42\end{array}$ & $\begin{array}{l}0.41 \\
0.38\end{array}$ & $\begin{array}{l}0.66 \\
0.61\end{array}$ & $\begin{array}{l}0.70 \\
0.71\end{array}$ \\
\hline \multirow[t]{2}{*}{ Stearic } & $\begin{array}{l}\text { CL2 } \\
\text { CL2 }\end{array}$ & $\begin{array}{l}\text { S/All } \\
\mathrm{R} / \mathrm{P}\end{array}$ & $\begin{array}{l}0.50 \\
0.54\end{array}$ & $\begin{array}{l}0.46 \\
0.56\end{array}$ & $\begin{array}{l}0.68 \\
0.68\end{array}$ & $\begin{array}{l}0.63 \\
0.70\end{array}$ \\
\hline & $\begin{array}{l}\text { AA3 } \\
\text { AA3 }\end{array}$ & $\begin{array}{l}\text { S/All } \\
\text { R/T }\end{array}$ & $\begin{array}{l}0.52 \\
0.50\end{array}$ & $\begin{array}{l}0.45 \\
0.54\end{array}$ & $\begin{array}{l}0.84 \\
0.87\end{array}$ & $\begin{array}{l}0.82 \\
0.84\end{array}$ \\
\hline
\end{tabular}

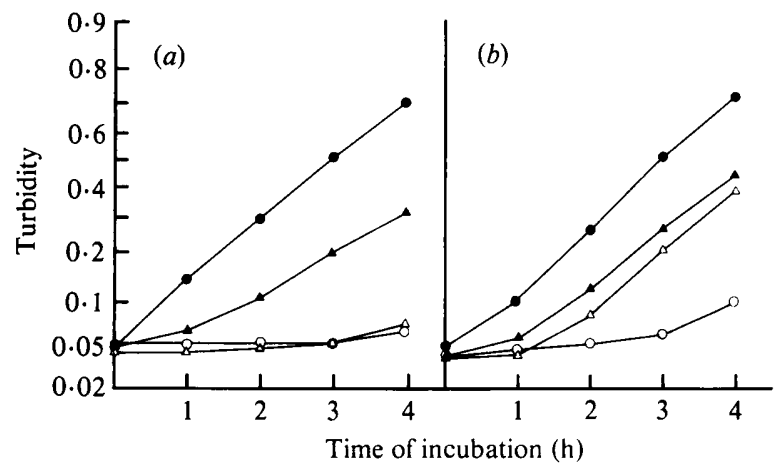

Fig. 4. Effect of linoleic acid and cholesterol on the growth of the cadmium-sensitive $(a)$ and cadmium-resistant $(b)$ variants of $S$. aureus strain 9789 at $\mathrm{pH} 7\left(\boldsymbol{O}, 4 \mu \mathrm{g}\right.$ linoleic acid $\mathrm{ml}^{-1}$ and $10 \mu \mathrm{g}$ cholesterol ml ${ }^{-1} ; \mathrm{O}, 4 \mu \mathrm{g}$ linoleic acid $\mathrm{ml}^{-1}$ only) and $\mathrm{pH} 5.5\left(\Delta, 4 \mu \mathrm{g}\right.$ linoleic acid $\mathrm{ml}^{-1}$ and $10 \mu \mathrm{g}$ cholesterol ml-1 $; \Delta, 4 \mu \mathrm{g}$ linoleic acid $\mathrm{ml}^{-1}$ only).

linoleic acid $\mathrm{ml}^{-1}$, the inhibitory effect of the fatty acid was reduced. This was also true of strain 9789 (Fig. 4). But even in the presence of cholesterol the advantageous effect of the penicillinase and cadmium resistance plasmids against the inhibitory action of linoleic acid at pH 5.5 was still apparent. Cholesterol was also able to reduce the inhibitory effect of myristic acid on strain CL2, but in strain 9789 it reduced inhibition of the cadmium-resistant variant only. 
In strain AA3, cholesterol reduced the inhibitory activity of linoleic acid at both $\mathrm{pH} 5.5$ and $\mathrm{pH} 7$ and of myristic acid at pH 5.5. However, there was no differential effect on the plasmid-carrying or plasmid-free variant.

The various cholesterol esters had no effect on growth of sensitive and resistant variants at either $\mathrm{pH}$ value.

\section{Inhibition of $S$. aureus by squalene and skin steroids}

There appeared to be no significant effect of squalene on the growth of isolates with or without plasmids at either $\mathrm{pH}$. The general effect of steroids seemed to be stimulatory at $10 \mu \mathrm{g} \mathrm{ml}^{-1}$ but inhibitory at $100 \mu \mathrm{g} \mathrm{ml}^{-1}$. There was no special effect on strains bearing penicillinase plasmids or tetracycline resistance plasmids.

\section{DISCUSSION}

Although $S$. aureus is rarely found on normal human skin, it is often present on diseased skin even on areas regarded as clinically normal (Noble, 1981). Fatty acids have often been included amongst the factors thought likely to suppress organisms on skin, and this may indeed be true for the streptococci. However, Heczko \& Kasprowicz (1976) have shown that staphylococci have higher m.i.c. values for various fatty acids including linoleic acid than have propionibacteria, the latter being very common inhabitants of both normal and diseased skins. Some other mechanism presumably governs the rarity of $S$. aureus on normal skin.

In many patients with skin diseases the proportion of antibiotic-resistant $S$. aureus cells is often similar in the nose and on the skin surface, but when differences do occur, there are usually more resistant variants on the skin than in the nose (Noble, 1977; Naidoo, 1980). The experiments reported here show that, although many components of skin lipid have no differential effect on isolates bearing plasmids, linoleic acid is selective for cells bearing the penicillinase plasmid at $\mathrm{pH} 5.5$ but not at $\mathrm{pH}$ 7. The effect persisted even in the presence of cholesterol which reduced the inhibitory effect of linoleic and myristic acids.

The genes governing the resistance to inhibition by linoleic acid in the clinical strain Git and strain NCTC 9789 are apparently not those specifying the production of penicillinase, since the same effect is obtained with cultures carrying the cadmium resistance plasmid. The mechanism of resistance has not been determined, but the genes which specify metal ion resistance might also be responsible since resistance, for example, to cadmium involves an alteration in the cell membrane leading to exclusion of the metal ion (Chopra, 1975). Exclusion of the fatty acid may be mediated in the same way. However, it is possible that a separate gene mediates fatty acid resistance.

The conditions used in these experiments may not be directly relevant to those in vivo. The alcohol used to dissolve the lipids may have affected their physical dispersion and their effect on the cells in a manner not encountered in vivo. Lipid on skin is a complex mixture of a variety of substances including the free fatty acids. However, as yet, no suitable model for studying the effects of lipids on plasmid-carrying bacteria in vivo is available.

The Wellcome Trust is thanked for providing support. I am grateful to Dr K. G. H. Dyke for helpful discussion. This work forms part of a thesis presented to the University of London for the degree of Doctor of Philosophy.

\section{REFERENCES}

Altenbern, R. A. (1977). Effect of exogenous fatty acids on growth and enterotoxin B formation by Staphylococcus aureus 14458 and its membrane mutant. Canadian Journal of Microbiology 23, 389-397.

Asheshov, E. H. (1966). Chromosomal location of the genetic elements controlling penicillinase production in a strain of Staphylococcus aureus. Nature, London 210, 804-806.

Asheshov, E. H. (1969). The genetics of penicillinase production in Staphylococcus aureus PS80. Journal of General Microbiology 59, 289-301.

Butcher, G. W., King, G. \& Dyke, K. G. H. (1976). Sensitivity of Staphylococcus aureus to unsaturated 
fatty acids. Journal of General Microbiology 94, 290-296.

Chopra, I. (1975). Mechanism of plasmid-mediated resistance to cadmium in Staphylococcus aureus. Antimicrobial Agents and Chemotherapy 7, 8-14.

Clewell, D. B. \& Helinski, D. R. (1969). Supercoiled circular DNA-protein complex in Escherichia coli: purification and induced conversion to an open circular DNA form. Proceedings of the National Academy of Sciences of the United States of America 62, 1159-1166.

Greenway, D. L. A. \& Dyke, K. G. H. (1979). Mechanism of the inhibitory action of linoleic acid on the growth of Staphylococcus aureus. Journal of General Microbiology 115, 233-245.

HeczKo, P. B. \& KaSprowicz, A. (1976). Epidemiological and ecological studies on mechanisms of staphylococcal carriage. Staphylococci and Staphylococcal Diseases: Proceedings of III International Symposium on Staphylococci and Staphylococcal Infection, pp. 935-940. Edited by J. Jeljaszewicz. Stuttgart: Gustav Fischer Verlag.
Meyers, J. A., SANChez, D., Elwell, L. P. \& Falkow, S. (1976). Simple agarose gel electrophoretic method for the identification and characterization of plasmid deoxyribonucleic acid. Journal of Bacteriology 127, 1529-1537.

NAIDOo, J. (1980). Gain and loss of antibiotic resistance in Staphylococcus aureus on skin. Ph.D. thesis, University of London.

NoBle, W. C. (1977). Variation in the prevalence of antibiotic resistance in Staphylococcus aureus from human skin and nares. Journal of General Microbiology 98, 125-132.

NoBle, W. C. (1981). Microbiology of Human Skin. London: Lloyd-Luke (in the Press).

Novick, R. P. (1963). Analysis of transduction of mutations affecting penicillinase formation in Staphylococcus aureus. Journal of General Microbiology 33, 121-123.

Sonstein, S. A. \& Baldwin, J. N. (1972). Loss of the penicillinase plasmid after treatment of Staphylococcus aureus with sodium dodecyl sulphate. Journal of Bacteriology 109, 262-265. 